\title{
The effect of the feeding system on calf performance and meat quality
}

\author{
M. Zymon ${ }^{1}$ and J. Strzetelski \\ National Research Institute of Animal Production, \\ Department of Animal Nutrition and Feed Science \\ 32-082 Balice, Poland
}

\begin{abstract}
The study comprised 20 bull calves, divided into 2 groups of 10 animals, aged from 7 to 90 days. The calves were fed milk replacer or whole milk for the first 56 days. The concentrate mixture, fed ad libitum, contained ground cereals, soyabean meal and minerals. At 90 days of age the calves were slaughtered and samples of meat were taken from the M. thoracis. The concentrate intake, daily gains and final body weight were higher in the calves receiving whole milk than those fed replacer. The meat from milk-fed calves had a higher protein and n-3 PUFA content, but a lower n-6/n-3 ratio than calves fed milk replacer.
\end{abstract}

KEY WORDS: calf, performance, feeding, milk, milk replacer

\section{INTRODUCTION}

In new milk replacers for calves, milk protein has been largely replaced with plant (e.g., legume) protein. These preparations contain refined fat and probiotic bacteria acids, which ensure good feed conversion by stabilizing intestinal flora (Kolar and Wagner, 1991).

The aim of the study was to compare the performance of calves and their meat quality depending on the type of liquid feed used during the milk feeding period.

\section{MATERIAL AND METHODS}

The experiment was carried out on 20 Black-and-White bull calves, aged from 7 to 90 days, randomly assigned to 2 groups of 10 animals each. Calves in both groups

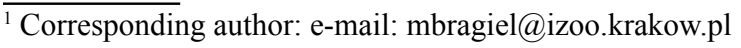


were fed ad libitum a concentrate containing, \%: ground barley 40.5, ground wheat 30.5 , wheat bran 13 , soyabean meal 13 , and minerals 3 .

For the first 56 days the calves were fed liquid feed: whole milk or the milk replacer, Sanolac Rot SANO. The nutrient content in the feeds was determined using standard procedures. The energy and protein value of feeds, components of mixtures and daily rations were established according to IZ-INRA (2001) standards. The animals were fed individually, and the intake of feed and body weight (initial, at weaning and final) were monitored. At the end of the experiment (90 days of age) the calves were slaughtered and samples of meat were taken from the $M$. thoracis (MT) for analysis.

The nutrient content of meat was determined according to AOAC (1990); the fatty acid composition was analysed in extracted fat (Folch et al., 1957) by gas chromatography (Varian 3400, 105 m column).

The results were analysed statistically using the one-way analysis of variance procedure of SAS Enterprise Guide (2002). The differences were assumed to be not significant at $\mathrm{P}>0.05$.

\section{RESULTS}

The chemical composition and nutritive value of liquid and concentrate feeds are given in Table 1 .

Table 1. Chemical composition and nutritive value of feeds

\begin{tabular}{lcccccccc}
\hline Feed & $\begin{array}{c}\text { Dry } \\
\text { matter } \\
\%\end{array}$ & $\begin{array}{c}\text { Crude } \\
\text { protein } \\
\%\end{array}$ & $\begin{array}{c}\text { Ether } \\
\text { extract } \\
\%\end{array}$ & $\begin{array}{c}\text { Crude } \\
\text { fibre } \\
\%\end{array}$ & $\begin{array}{c}\text { Ash } \\
\%\end{array}$ & $\begin{array}{c}\text { PDIN }^{1} \\
\text { g }\end{array}$ & $\begin{array}{c}\text { PDIE }^{1} \\
\text { g }\end{array}$ & UFL $^{1}$ \\
\hline Concentrate & 100 & 18.48 & 1.56 & 5.29 & 5.21 & 127 & 126 & 1.16 \\
mixture & 86.2 & 15.93 & 1.35 & 4.56 & 4.49 & 109 & 109 & 1 \\
& & & & & & & & \\
Milk replacer & 100 & 20.5 & 20.4 & - & 8.29 & - & - & - \\
& 97.33 & 19.95 & 19.86 & - & 8.07 & - & - & - \\
& & & & & & & & \\
Whole milk & 100 & 27.9 & 34.8 & - & - & - & - & - \\
& 12.35 & 3.45 & 4.30 & - & - & - & - & - \\
\hline
\end{tabular}

${ }^{1}$ IZ-INRA (2001): UFL - unit of energy for milk production; PDIN - protein digested in the small intestine depending on rumen degraded protein; PDIE - protein digested in the small intestine depending on rumen-fermented organic matter

The intake of liquid feed per calf was $317 \mathrm{~kg}$ in the milk group and $264 \mathrm{~kg}$ in the milk replacer group (44 $\mathrm{kg} \mathrm{DM})$. During the whole rearing period the intake of concentrate and nutrients by calves from the milk group was about $35 \%$ higher 
$(\mathrm{P}<0.01)$ than by those from the milk replacer group (Table 2), although feed efficiency was equal in both groups.

Calves receiving whole milk had a higher body weight at weaning (by about $30 \%$ ), higher final body weight (by about $20 \%$ ), and better daily weight gains during the liquid feeding and whole rearing period than the milk-replacer calves.

The meat from calves fed whole milk had a higher $(\mathrm{P}<0.01)$ crude protein content $(20.66 \%)$ than that from calves fed milk replacer $(19.42 \%)$ and a higher n-3 PUFA content, especially linolenic acid ( 0.80 and $0.56 \%$, respectively), EPA ( 0.70 and $0.38 \%$, respectively), and DHA ( 0.44 and $0.23 \%$, respectively). The n-6/n-3 PUFA ratio in the meat from calves fed whole milk (7.1) was nearly half of that in meat from calves receiving milk replacer (13.2).

Table 2. Fattening results of calves

\begin{tabular}{|c|c|c|c|c|}
\hline Item & Milk replacer & Whole milk & $\mathrm{P}$ & SEM $^{1}$ \\
\hline Initial body weight, $\mathrm{kg}$ & 43.20 & 46.05 & 0.26 & 1.24 \\
\hline Body weight at weaning (56 days), $\mathrm{kg}$ & 62.90 & 81.80 & $<0.01$ & 2.96 \\
\hline Final body weight (90 days), $\mathrm{kg}$ & 97 & 116.45 & $<0.01$ & 3.24 \\
\hline Daily weight gain from 7 to 56 days, $\mathrm{g} /$ day & 406.25 & 754.74 & $<0.01$ & 47.96 \\
\hline Daily weight gain from 7 to 90 days, g/day & 659.07 & 877.65 & $<0.01$ & 34.58 \\
\hline \multicolumn{5}{|l|}{ Daily intake of: } \\
\hline liquid feed, $\mathrm{kg}$ & 5.43 & 6.72 & $<0.01$ & 0.21 \\
\hline concentrate, $\mathrm{kg}$ & 1.03 & 1.40 & $<0.01$ & 0.06 \\
\hline dry matter, $\mathrm{kg}$ & 0.89 & 1.21 & $<0.01$ & 0.05 \\
\hline crude protein, $g$ & 164 & 223 & $<0.01$ & 9.43 \\
\hline $\mathrm{PDIN}^{2}, \mathrm{~g}$ & 112 & 152 & $<0.01$ & 6.46 \\
\hline $\mathrm{PDIE}^{2}, \mathrm{~g}$ & 112 & 152 & $<0.01$ & 6.46 \\
\hline $\mathrm{UFL}^{2}$ & 1.03 & 1.4 & $<0.01$ & 0.59 \\
\hline
\end{tabular}

${ }^{1}$ SEM - standard error of the means; differences are not statistically significant at $\mathrm{P}>0.05$

${ }^{2}$ IZ-INRA (2001): UFL - unit of energy for milk production; PDIN - protein digested in the small intestine depending on rumen degraded protein; PDIE - protein digested in the small intestine depending on rumen-fermented organic matter

\section{DISCUSSION}

According to numerous authors, the lower weight gains of calves fed milk replacers compared with milk-fed calves result from the lower digestibility of milk protein substitutes (Toullec et al., 1994; Strzetelski et al., 2001). Legume proteins are less susceptible to proteolysis than milk protein (Jenkins, 1980), contain antinutritional factors, and are not coagulated by rennet, which increases abomasal emptying and decreases protein digestibility in the abomasum and small 
intestine (Van Kempen and Huisman, 1991). The better production results of milkfed calves might also have been caused by the higher fat level in the daily ration of liquid feed (Doppenberg and Palmquist, 1991).

The differences found in the composition and proportions of fatty acids in the calves' meat fat show that liquid feeds used in the milk feeding period can affect meat quality, as the calves of both groups received the same solid feed. It can be suggested, however, that these differences result largely from the greater concentrate intake by milk-fed calves compared with those receiving milk replacer.

\section{CONCLUSIONS}

Milk feeding of calves to 56 days of age produces much better results than milk replacer feeding. Calves receiving whole milk show higher weight gains and achieve higher body weights. In addition, the meat of milk-fed calves is of a higher nutritive value and has a more beneficial fatty acid composition from the viewpoint of human health.

It is recommended that farmers should use whole cow's milk in calf rearing, especially now when the milk quotas established by the European Union result in a surplus of milk production.

\section{REFERENCES}

AOAC, 1990. Association of Official Analytical Chemists, Official Methods of Analysis. 15th Edition. Arlington, VA

Doppenberg J., Palmquist D.L., 1991. Effect of dietary fat level on feed intake, growth, plasma metabolites and hormones of calves fed dry or liquid diets. Livest. Prod. Sci. 29, 151-166

Folch J., Less M., Sloane-Stanley G.M., 1957. A simple method for the isolation and purification of total lipids from animal tissues. J. Biol. Chem. 226, 497-509

IZ-INRA, 2001. Standards for Cattle, Sheep and Goats Nutrition (in Polish). Research Institute of Animal Production, Kraków (Poland)

Jenkins K.A., Mahadevan S., 1980. Susceptibility of proteins used in calf milk replacers to hydrolysis by various proteolytic enzymes. Can. J. Anim. Sci. 60, 907-914

Kolar C.W., Wagner T.J., 1991. Alternative protein use in calf milk replacer. In: J.H.M. Metz, C.M. Groenstein (Editors). New Trends in Veal Calf Production. Pudoc, Wageningen, pp. 211-215

SAS Enterprise Guide, 2002. Version 2.0, SAS Institute Inc., Cary, NC

Strzetelski J., Niwińska B., Maciaszek K., 2001. Effect of protein source in liquid feeds and physical form of concentrate fed during the milk-feeding period on calf performance (in Polish). Rocz. Nauk. Zoot. 28 (2), 143-153

Toullec R., Lalles J.P., Bouchez P., 1994. Replacement of skim milk with soya bean protein concentrates and whey in milk replacer for veal calves. Anim. Feed Sci.Tech. 50, 101-112

Van Kempen G.J.M., Huisman J., 1991. Introductory remarks: some aspects of skim-milk replacement by other protein sources in veal-calf diets. In: J.H.M. Metz, C.M. Groenestein (Editors). New Trends in Veal Calf Production. Pudoc, Wageningen, pp. 201-205 